\title{
Care for the other: lessons from the streets of Athens
}

\section{Angie Voela}

\section{University of East London}

\begin{abstract}
Austerity in Greece resulted in poverty, political and social turmoil and intense debates about collective identities, citizenship and the future. One of the main arguments has been that the Greeks should re-evaluate their relationship with the past and their over-reliance on national narratives. The task of re-evaluation can only be accomplished in the public spheres of politics and culture, where individual and collective voices gradually transform the imaginary significations that animate the social body. One such voice is Rhea Galanaki, a novelist with a long and distinguished presence in the Greek and European letters. The present article draws on her 2015 novel I Akra Tapeinosi (The Utter Humiliation) in order to flesh out a feminist political vision for the future. This vision draws inspiration from women's struggles against patriarchy in past decades, and resonates with the concepts of vulnerability and care, contributing to thinking a compassionate alternative to the politics of despair within and beyond the Greek borders.
\end{abstract}

\section{Keywords}

care, time, austerity, Greece, patriarchy, Rhea Galanaki

The economic crisis of 2008 has had deep and dramatic consequences in Greece. Austerity threw into relief the correlation between ill health and poverty (Christodoulou et al., 2016), whilst the disintegration of the social fabric following the radical economic restructuring has been directly linked with the resurgence of racism and fascism (Halokopoulou and Vlandas, 2015). As Greece prepares to exist from the emergency economic measures, Europe still grapples with the grim 
prediction that we stand before an uncharted future for which no past could have prepared us (Streeck, 2016; Varoufakis, 2011: 3).

Between 2008 and 2015, when the indignation of common people against the Troika-led austerity spilled into the streets of Athens, academics like Kostas Douzinas (2013) saw hope for radical change, just as Judith Butler (2011) had celebrated the transformative power of occupying the streets and squares of the world's metropoles. Quickly, however, it became apparent that indignation has its limitations when many and often conflicting agendas collide, or when people begin to deploy the discourse of traditional enemies (e.g. Germany) and trite metaphors like 'lessons from history' (499) in order to gloss over their incapacity to comprehend current events (Theodossopoulos, 2014, Knight, 2012).

These observations are often matched by a critical examination of Greek attitudes. Tolis Malakos argues that the roots of the crisis lie in the nation's propensity to blame others for their fate. The Greeks, Malakos continues, lack the critical capacity to turn the lens inwards and think critically, in order to transcend their fantasies and self-referential relativity (2018: 187). Having bought into the myth that Greece is the birthplace of European identity, the Greeks imagine themselves as ruins, and are unable to perceive the other in their otherness (2018: 190). This attitude goes hand in hand with the loss of the capacity to remember, the kind of remembering that follows the experience of losing and relinquishing a loved object. 'We live in a graveyard', notes Malakos, 'we are in denial [...] but we still need to learn to weep; to learn living in absence. That would be some kind of start' (2018: 191).

Others describe the Greeks as remaining in a state of blocked mourning (Glynos and Voutyras, 2016), which constitutes part of a wider and more global crisis of representation. Subtended by nationalist discourses which pre-dated the 2008 financial crisis by several decades, the polarization of the debate to an austerity/anti-austerity opposition caused a 'failure to process loss' (2016: 203) further resulting in two modes of existence, melancholia and ressentiment. Thus, the Greeks find themselves in the grip of an ideological phantasy of loss and the fear of collapse of the potent national self-image.

Theoretically compelling though they are, such assessments do not always engage with imagining ways forwards. Admittedly, this is not necessarily the remit of political theory. This task is to be accomplished in the communities and in the sphere of culture, where individual and 
collective voices gradually alter the social imaginary significations that animate the social body (Castodiadis, 1997:7).

These are the issues with which Rhea Galanaki, a progressive novelist of four decades, grapples in her 2015 novel, I Akra Tapeinosi (The Utter Humiliation): how can we imagine a way forward beyond guilt and innocence? How can we turn the lens inwards, putting the past to rest, while preparing for an unchartered future? This is not a challenge for the Greeks only. Maurizio Lazzarato’s (2012) 'indebted man' became one of the most prevalent metaphors of subjectivity under neoliberal global financialization precisely because it captures the radical break with previous conceptualisations of identity based on individuality and freedom. Indebtedness is an indefinite condition. It spells indefinite financial and psychic bondage. The crisis, as Berardi points out, addresses us with a vague and unsettling demand, namely that we must forfeit a way of life: 'We must forfeit civilization. But why should we accept this exchange?' (2012: 63).

In Akra Tapeinosi Rhea Galanaki is tapping into the unconscious of the indignant middle class, bringing to the fore the spectre of poverty and the death of the dream of infinite eudemonia. The novel starts from a 'ground zero' of memory, the muddled past-and-present of two amnesiac old ladies who live, forgetful and forgotten, in retirement accommodation. The two pensioners, an artist and a history teacher, once belonged to the Polytexneion generation, had lived comfortable middle-class lives and had first hand-experience of the feminist struggles of the sixties. A few pages into the novel the reader understands that the seemingly formidable challenges of the present do, after all, have a precedent: the women's struggles against patriarchy. Disguised as an impulsive and dangerous excursion into the streets of Athens on the day of the largest and most violent demonstration on the $12^{\text {th }}$ of February 2012, the novel surveys Greece's chaotic present and recent past, and drafts a response to the question of how to imagine a different way forward.

This, as we will see below, is a complex and painful operation starting with Galanaki's vision of a feminist alternative to avarice, lack of compassion and, more important, despair at a time of crisis. Lost in the streets of Athens, the two women are raised by the author into sublime examples of mutual support and care, positing a serious proposition: it is the forgotten, the forgetful and the vulnerable that could show a different way forward, especially where the 
'strong' and the 'sharp' have failed. Galanaki's imaginative response, I will argue below, resonates with the concepts of vulnerability and care developed by Adriana Cavarero (2016), and provide an excellent insight into thinking a compassionate alternative to the politics of despair beyond the Greek borders.

I Akra Tapeinosi is also a study of time. As a writer who has repeatedly grappled with the thorny issues of national and personal memory, Galanaki incorporates in her approach a concern of time very different from the obsession with the glorious past (xxxx forthcoming). This concern is two-fold; on the one hand, it pays attention to the duration and different tonalities of time (Baraitser, 2017), the old women's long years of waiting, silence, suffering, and apparent idleness, which come to explosive fruition in the few weeks of the novel's unfolding events. On the other hand, this long view of time chimes with the effects of psychoanalytic interpretation: traversing fantasies of glory, freeing the subject from the burdens of the past but also removing the fake comfort often found in cherished myths and illusions.

The massive protests in the streets of Athens gave rise to hope of a new era of collective politics, consonant with anti-capitalist protests around the globe. Bulter (2011) trusts the enormous potential of the people coming together in the streets to protest. Galanaki exacerbates this move: what happens when people do not just take to the streets but remain there, inhabiting the streets as homeless? This is what occurs to the two heroines who are unable to find their way home, having forgotten their residential address.

Homelessness is a nightmare for the middle class. The permanent loss of home, which the Greek expression 'to be left out in the street' captures accurately, is an expression of absolute destitution. Galanaki does not question the harsh reality of losing one's home to repossession, but the mental state of homeliness and homelessness. Has home always been a happy abode for women? Has it not often been an uncanny locus or a locus of anxiety (Kokoli, 2106), or a prison separating them from the polis (public sphere)? Could this knowledge and paradigm of powerridden captivity help us disentangle the real from the phantasmatic consequences of being indebted and (economically) bound to the other, to a male, the capital or Europe? Could the wisdom of the two pensioners be the starting point for separating national bankruptcy from an attitude of subjection and indebtedness that the neoliberal crisis seems to encourage? 
As the work of an intellectual who belongs to the Greek left ${ }^{1}$ Galanaki's I Akra Tapeinosi chimes with debates about the future of European identity and critical responses to neoliberal austerity, which are much wider in scope than the Greek economic crisis. I Akra Tapeinosi, I shall argue below, adds a Greek voice to the wider concerns of our time. By inviting us to reconsider the slow time of generations, the forgotten and the repressed, the novel traces the minute but momentous shifts that any serious re-signification of the present ought to take into account in order to support a genuine politics of care in the future.

Below I start by offering a critical reading of the novel, focusing on three main aspects; first, the nexus of human relations and care (or lack of) that constitutes the living reality of the two old women; second, the symbolic message in their participation in the demonstration of the 12 th of February and the events as they unfolded in the almost theatrical tragic setting of the Athenian streets; and third, the experience of homelessness which completes the process of the resignification of the past. Following this critical reading, I discuss how a feminist regime of care can be mobilized to chime with an effort to turn the lens inwards while contributing to wider debates for a less neoliberal European future.

\section{INSIGNIFICANT ACTS IN THE NAME OF A LOST CAUSE}

I Akra Tapeinosi starts with one of the two women, Teiresia, staring out of her window, a silent observer of the grey urban landscape and life in the street below, among them a homeless man living at the doorstep opposite her building. Teiresia sets the mood of the novel: 'What is the passage of time, if not the need for consolation? (13). A consolation for what, one might ask. Her flatmate, Nymphe, used to be a painter and the wife to a powerful politician. Teiresia and Nymphe are not nostalgic of the past. They are content with their 'new' family, an atypical assemblage of individuals thrown together by chance: Danae, their divorced social worker, and

${ }^{1}$ http://www.tovima.gr/books-ideas/article/?aid=411377

\section{https://www.lifo.gr/team/selides/57786}


her daughter; Yasmin, the immigrant cleaner and her son; Katerina, thei carer and mother of a wayward Golden Dawn thug; and Orestes, Nymphe's anarchist activist son.

Teiresia, has symbolically rejected the past by changing her given name, Theeresia, the hellenized version of Teresa and a name with imperial connotations (as in Maria Teresa of Austria). Her new name is the feminine of Teiresias, the grammatically masculine appellation of the mythical seer in Oedipus Rex. Teiresia is proud of her historical gender correction she has performed (22), since, as she reminds us, everybody knows that the ancient seer was also a woman. Likewise, Nymphe, christened Theo-nymphe, which literally means 'the bride of God', has dropped the Christian God from her name, leaving herself with 'nymph', evocative of Greek mythology. Teiresia reckons that her bold gesture brings forth to the $21^{\text {st }}$ century the forgotten ancient female wisdom.

The group portrait is completed by 'the patriarch', as Nymphe and Teiresia call him. At first we do not know who the fearful 'patriarch' is. Eventually we learn that he is the doctor in charge of the secure accommodation, who prescribes their medication, keeping the two women house-bound, lethargic and confused, in line with neoliberal protocols of medicalised care (Lombardo 2016). The patriarch is a resigned middle-aged man who feels too old to take to the street, and uses cynicism as a defence against his disenchantment (131). Trapped in unimportance, the patriarch, like all patriarchs, exercises authority on his powerless patients. Thus, Teiresia and Nymphe experience life as a distant, mediatized reality. When Teireisa asks Nymphe: 'What does Athens mean for you?' the later replies without hesitation: 'It is what I see on TV' (61). Television represents the levelling of individual memory effected by the synchronization of digital reality (Hutnyk, 2012). Trapped in their home, medicalized and detached, the two women live the modern unheimlich (Virno 2004: 38), the un-homeliness in their own home and city, typical of late capitalism and entrenched long before the advent of the financial crisis. In that sense, the loss of memory from which they suffer, is not a sign of old age only, but a symbolic representation of a generalized public inertia, a neoliberal condition which chimes with the greying out of the urban landscape (loss of distinctness of individuals, massification) and a loss of the intensity of living (Stiegler, 2013).

But if neoliberalism has already resulted in collapsing distinct temporalities into simultaneity, exacerbating one's sense of incapacitation and amnesiac entrapment, how is one 
jolted into action? For many political theorists and philosophers, action arises when we can no longer tolerate our present conditions of being, when it is no longer a matter of "discovering" ourselves in a dwelling or heimat, but of "crossing the line to a new and improbable identity" (Rajchman, 1991, p.13, emphasis added). Galanaki has repeatedly explored this radical break with the past in her work (xxxx), with heroes that do not hesitate to radically alter their lives when they felt they no longer lived in accordance with their political or ethical beliefs. In I Akra Tapeinosi Galanaki invites us to focus on a much slower temporality, the long and apparently unproductive stretches of time, the caesura that has duration, as Baraitser puts it (2017: 7). Observing this caesura is important. Baraister situates its value theoretically between Badiou's paradigm of history as truth (eternal) and a Deleuzian approach which proposes that 'all is movement' (2017: 12). Baraitser argues that stasis can produce change 'through someone's capacity to paradoxically remain faithful (to use Badiou's term) to the un-event, the not-yethappening, indeed what Badiou would call the situation that is not yet supplemented by the event' (2017: 13). In this context, the temporal tropes of waiting, staying, delaying and enduring become significant for exploring 'the potential for transcending the immanence of our own historical moment in precisely the places that it looks impossible to happen' (2017: 14).

Galanaki, I would argue, adopts a similar view of time, foregrounding a fragile fidelity to the (old) feminist cause, by bringing it to bear directly onto the present. Patriarchal repression, which we might have considered as a thing of the past, is transformed into a paradoxical and poignant dependence on the modern patriarch, the doctor, or the capitalist who provide security and care. Coming to think of this new domestication as unbearable condition, and, perhaps, a valid metaphor of all conditions of dependence and indebtedness, is indeed an act of fidelity to things yet to come from the past. The impetus for subverting this new domesticity does not come for an anarchist rebellion, like Orestes', , but from enduring and remaining faithful to the old political and personal struggles against patriarchy. More important, during the long time of (amnesiac) waiting, the psychic reserves for the capacity to change are kept alive by enduring, watching, observing and performing small acts of resistance, like Teiresia's renaming of herself and disengaging from one's biological family. Paying attention to slow time means that such acts do not go unnoticed; they provide the bridge between idle times and a new cause, further demonstrating the value of waiting as fertile, calculable time. Thus, Galanaki seems to suggest, in thinking our way forward we should not so much concern ourselves with who is (not) to 
blame or who will lead a rebellion but with what we have done by way of fidelity to an unfinished cause.

\section{VULNERABILY AND CARE IN THE STREETS OF ATHENS}

The transition to the streets of Athens throws the two women into an accelerated present we could call a conflagration of times (1992: 269). This is the terms Lacan uses to describe Greek tragedy and the convergence of past, present future in the present of the theatrical scene. Indeed, Teiresia refers to the streets of Athens as a tragic scene, with the house of Parliament (Voulé) as the palace (97), the protestors as the chorus of citizens, and herself and Nymphe as protagonists in a Greek play.

The foray into the streets of Athens is, at first, carnivalesque and anarchic. The swelling demonstration feels like a celebratory procession (85). The two women cry out: 'This is it!' (87). 'It' refers to the immediacy of experience and the new-found resonance of the word 'to participate'. 'It' no longer happens on television (89). Teiresia and Nymphe smile conspiratorially to one another, having banished the demons of loneliness, illness and slavery (89).

Sassen (2013) considers the city as a space where the powerless make history, and the streets as the place which alters the character of powerlessness. Galanaki, however, has her gaze fixed beyond the jubilation caused by the first taste of freedom. She is interested in the deeper transformation which starts when the two women, exhausted by the march, decide to go home, only to realise that they do not quite know where they live. Their experience of the long night of riots is described by Galanaki in visual terms, as a succession on theatrical postures: Teiresia and Nymphe stand upright, marching together with the protestors (101). Then, exhausted, they lean onto one another for support. At the peak of the riots, Teireia stands erect, lifting her hands like a priestess having visions of disaster (104). Nymphe cowers in terror, burying her head in Teireisa's lap. Teireisa feels tragically alone and calm at that moment, but unexpectedly collapses in a heap, dizzy from the tear gas. Nymphe falls on top of her in despair (108). Teiresia hovers in and out of consciousness (109). Nymphe pulls and tugs and her limp body, wailing. The 'entangled bodies' (142) continue to support one another through the maenadic night. They 
seek refuge, like suppliants, in a shopping arcade near Stadiou Street. Teireria now regrets not being able to foresee the outcome of their foray into freedom, and, as she calls it, the nostalgia for freedom eventually crushing dreamers and 'women like you' (145). But immediately she reprimands herself for wishing to go back to the flat, a capitulation which would have meant that 'they had not moved an inch' (146). Now the self-professed seer begins to see the past clearly, especially her imprisonment in her own fears. In the thick of the riots Teiresia gains clarity of vision, seeing herself and Nymphe as two pitiful, dirty and dishevelled old ladies.

Making oneself the object of one's gaze is regarded by psychoanalysis a decisive moment which brings one closer to a radical restructuring of subjectivity (Voela, 2011: 175). Galanaki is well aware of the importance of this move and has often made it a pivotal point in the psychic life of her heroes. In I Akra Tapeinosi seeing oneself differently relates to two important psychic shifts: on the one hand, the dissolution of the phantasmatic object (e.g. the fear of losing the hateful sheltered life), and on the other, the acceptance of the infernal present as one's inevitable choice. The latter further chimes with the psychoanalytic concept of the forced choice, owning up to one's fate, so to speak, with the dignity of a tragic hero. There is nothing fatalistic about this choice, which is liberating precisely in so far as it precludes blaming others for one's predicament, and leading to the traversal of the obstacles that keep a subject bound to its present condition. In that sense, Galanaki proposes something really radical: to look at the world around us at the very moment of conflagration and find courage and hope in it. This, I would argue, is the radical move through which the feeble-minded, vulnerable and indebted subject begins to feel the limits of their condition differently.

The political and collective importance of this moment is represented in the novel first by a spatial displacement. Teiresia and Nymphe retreat to Stadiou Street, accidentally finding themselves by the memorial plaque of Sotiris Petroulas, a young activist of their generation who was murdered by police on that very spot in 1965. Upon reaching the location, Teiresia feels it is her duty to pay homage to the old hero and mourn for him (151). Having done so, she raises herself from the ground and decisively says to Nymphe: 'That's enough, let's go'. (154).

There is more to this symbolic gesture that a senile old woman's flight of fancy. The capacity to mourn, not to be stuck in melancholic loss, lays the past to rest and, with it, regressive nostalgia. Butler argues that the mechanism of melancholia provides a way for 
understanding the institution of a distinction between social and psychic life. This distinction depends on the mutable social norms, which, in conjunction with psychic reality, form a 'variable' boundary for groups and individuals (Butler cited in Baraitser, 2017: 43). Let us accept that the night of the riots stands for the symbolic collapse of the social norms in an infernal, tragic present. Let us accept that the street events mark the end an era and the aporia at the beginning of another. In the burning streets of Athens, Galanaki opens up a psychic space where there was none. This psychic space is created, mobilized and 'liberated' with the abolition of melancholia. As Butler notes, it is psychic reality that is capable of changing the social norms, and not the other way round (cited in Baraitser, 2017: 40). Interestingly, radically, Galanaki turns the burning streets into the new horizon for rethinking the collective past, providing a virtual answer to Malakos' indictment of the collective Greek psyche. Paying homage to the past and moving forward is an act of fidelity to the broad ideology of a (feminist) Left which harks back to a time when women mobilised for freedom and dignity. Further, the old feminist struggles for difference supports the pursuit of difference in the present. Neoliberal patriarchy renders the vulnerable and the powerless invisible by conflating the 'psychic' with the 'mental', reducing individuals to their symptom and forcing them to see themselves as co-extensive with their 'disability' or affliction, denying subjects like 'women', the 'losers of history' and the 'powerless' their subjectivity. The psychic potential opened up in the streets of Athens is difference per se, namely, the very irreducibility of 'subjectivity' to 'illness'.

We have so far discussed I Akra Tapeinosi in terms of the radical shifts which create the conditions for thinking one's predicament differently. It would not be an exaggeration to say that the concern of Greek intellectuals with the restructuring of the Greek psyche, well-meaning though it is, often stops there. What seems to be missing is a slightly different dimension, namely, the vision of a new way which will truly transcends what was left behind. We could appreciate the symbolic significance of what Galanaki proposes at this point by turning to Cavarero's postural ontology and the concept of inclination. Galanaki's visual theatrical aesthetics, with the two women leaning on one another in a symplegma (complex) of care in the burning street of Athens, chimes with Cavarero's visual-aesthetic treatment of posture as a feminist response to masculine philosophies of independence and phallic rectitude. 
Critiquing the masculine philosophical traditions for ignoring the theoretical significance of the figure of the mother leaning towards the child, Cavarero proposes an ontology of inclination as a departure from the vertical axis that connotes phallic upright-ness and, by extension, orthotes (correctness) (2016: 53). For Cavarero, inclination is the human disposition par excellence (2013: 227). Maternal inclination does not concern mothers and children literally, but a maternal disposition to the orphan, the widow, the stranger (2013: 231). Cavarero proposes that postural ontology be placed alongside the existing philosophical systems, not in order to deny the usefulness of the former, but in order to expose their limits. Upon doing so, she adds, 'the change of perspective is remarkable' (2017: 231).

Can there be a better visual metaphor of the limitation of orthothes than the leaning, bending symplegma of Teiresia and Nymphe? Can there be a better example of inclination as a symbolic departure from the mastery of knowledge and power than two women supporting one another and, in doing so, discovering strength in each other's arms? In the streets of Athens dependence transforms into care during the night in which the rationalised handling of public life seems to collapse. The 'turning' towards the other, transcends disillusioned clarity by transforming vulnerability into an ethical feminine (and feminist) mode of being. Is there a better example than the two women sharing-supporting each other in solidarity in the streets of Athens?

A comment concerning chance should be added at this point. The two women are caught in the riots by chance. It could therefore be argued that they are not conscious political agents. Cavarero aligns inclination to the concept of clinamen, which is chance or tyche as a force of change that can derail the straight trajectory of order or meaning (2016: 95). She quotes Derrida: 'Only this deviation can change the course of an imperturbable destination and an inflexible order' (2016: 95). Chance and inclination, it could be argued, show a way of derailing and disrupting the prevalent mental state of capitalism as fixed fate (TINA) and fait accompli. It does not matter why one was caught up in the events. As Cavarero would say, the situation 'calls for a theatre of univocal exposure to others' (2013: 232) in which mother and child are both present, not as vulnerable baby and caring adult, but as emblematic of thinking vulnerability 'in terms of a primary relation' (2013: 233). Further, postural care transcends the tragic conceptualization of subjectivity defined by means of death, as care is a condition of birth, not death, in which 
natality, the concept of bringing-forth to the word, can be juxtaposed to endings even in the most unlikely context of devastation and death.

\section{THE HOMELESS POLITEIA AND THE MINOTAUR}

The Arendtian concept of natality, which Cavarero uses as an alternative to the concept of death in classical philosophy, has recently been used to theorize the birth of hope in the street protests of Cairo and other cities around the world (Elmarsafy, 2015). While the concept of a maternal city space intuitively makes sense, we could perhaps ask what happens when this mother is crazy, like Athens in Nympe's reckoning. And what happens to the dream of maternal containment when the children are left out in the streets?

Lost and disorientated, the two old women roam the streets of Athens aimlessly, until approached by a homeless man who invites them to 'his patch'. 'We have arrived at our destination!' (203) exclaims Nymphe upon reaching the place. Could anyone desire homelessness, recognising it as the destination they have been travelling to? Galanaki uses this paradoxical arrival to un-homeliness and non-belonging to dislodge bourgeois formations of homeliness and, most important, guilt. Homelessness pushes the hospitality of the city to the limit and jars with concepts of familiarity, safety and security. At the same time, the unhomeliness of the streets chimes with the Freudian unheimlich as a disturbance of consciousness by the return of the repressed (Freud, 1985: 371).

The reality of homelessness is harsh for the two women. No one in the streets goes by their real name, and 'nothing relates to the rights and wrongs of history as we knew them' (207). The two women are cared for, but also forced to beg and then robbed of their earnings by a 'helpful' beggar. Athens, Teiresia now understands, lies in ruins - said literally for the burnt streets and metaphorically for the fragments of Classical, Ottoman and Byzantine buildings visible in the urban landscape. As beggars, the two women experience 'akra tapeinosi' (utter humiliation). The word 'tapeinosi' connotes both humiliation and humility. In Christian iconography the phrase refers to the icon of the Crucifix placed by the altar, representing the becoming-human of Christ. 'Resurrection is promised through the pain of the living' (198) 
muses Teiresia, resorting to the collective religious representation of hope against the traumatic Real.

Yet, Galanaki does not pursue any imaginary salvation; she follows a different route: homelessness transcends the difference between the private and the public sphere and the imprisonment of the (indebted) woman into the oikos. At the same time, the homeless constitute a horizontal democracy, a headless community with no leader or king (209), a politeia (211) in the $5^{\text {th }}$ century AD Athenian sense. We could argue that participatory democracy is 'resurrected' from the utter humiliation of its citizens. It is fragile, precipitous and vulnerable, like the two women in the streets. It is not an idealised mythical polis but a real one. In this horizontal democracy, all citizens participate not only the ones who have the means to. In that sense, the streets of Athens are a radical site where the meek and the innocent are true actors and continue to be citizens even when dispossessed of their goods and their various strengths. Democracy, disengaged from property and privilege, is born in the streets of Athens, not in imitation of antiquity. This is fidelity to democracy that transcends the ancient Greek ideal.

Further, Galanaki chooses not to indulge in the dream of a new political ideal state but to exacerbate homelessness. She chooses to do so by allowing the two heroes to descent into hallucinatory exhalation, an aesthetic 'raving' in an orgy of colours. Weaned off their medication and no longer artificially kept 'well enough' (213), Nymphe starts experiencing the city in terms of intense colours (no longer a uniformly grey cityscape). Suddenly, she recalls the names of all the colours she used to know, and recites them one after the other. Wandering the streets of Athens, she comes across a mural of a tropical forest which she 'enters' as if an actual colourful jungle (236). Teiresia often loses herself in reverie with her. At moments of clarity Teiresia wonders if her friend will ever recover from her delirium. A voice in her head replies, to her and to whom it may concern: 'Do not wait for the magic bullet of a single word in life, a single 'yes' or a 'no'. This is just impossible in the jungle of modern day Athens [....] Do not chase an easy, one-word answer. You need to show courage' (236).

The creative capacities unleashed in these dire circumstances counterbalance the depressive melancholia of infinite loss by tapping into to the libidinal forces which remain free from the restrictions of socio-economic realities. Stiegler is among the philosophers who reckon that modern capitalism has reduced libidinal life into a short circuit of the drives, and argues for 
a profound restructuring of our psychic libidinal economy (Ross, 2011: 146) through reestablishing the 'long circuits of desire' against nihilism and libidinal dis-economy. As part of this effort, he also calls for fantasy (active imagination), attachment, care, philia (friendship as opposed to strife-eris), and actively observing life's various viscosities. Care in this context is attentiveness to the self and the other. It is neither mutual symbiotic existence nor mere altruistic self-denial, as Berardi rightly observes, but solidarity as the ability to share daily life (2012: 54). Care is a permanent inquiry often tinted with wounding, vulnerability and anxiety, pursuing we and infinite consistence instead of the sovereign ego (Stiegler, 2013: 41). Caring is a viable alternative to feeling trapped in one's predicament. The long circuits of desire and the struggle of the spirit pass through philia, aesthetic pleasure and the unleashing of creativity in its healingmaddening potential.

In Psychoanalysis transformation is often gauged in the analysand's dreams and use of language. For the two women, the sojourn in the streets of Athens ends when a homeless man, Pericles (another nod the $5^{\text {th }}$ century AD), guides them through the Athenian labyrinth and back to the flat, but not before Teiresia gets an insight into the labyrinth of History. The dream Galanaki conjures is both political and personal, a descent to a Dantean Purgatory of memory. Teiresia dreams that she descents the stairs of a burnt Athenian cinema. The film on screen is about the abduction of Europa by Zeus. The girl calmly climbs on the bull's back. A man sitting next to Teiresia asks her if she remembers how the myth ended, and Teiresia replies, with the confidence of the historian, that it ends with more unions between beasts and princesses that eventually gave birth to the Minotaur. The stranger tells her that it was actually the girl Europa that gradually transformed into a female Minotaur, managing to live for aeons by seeing through the stupid ploys of the love-smitten Thyseuses. At that moment Teiresia realises that the strange man speaking to her is her father and wakes up (277). The novel ends.

In order to survive, one needs to deal with little ruins and with the ruins little by little, instead of being enthralled by the question of how to proceed in the future. It should be added at this point, that this is not the first time Galanaki employs the metaphor of the labyrinth for a critique of collective Greek identity. In O Aionas ton Lavyrinthon (The Century of Labyrinths) (2002), a political, ideological and aesthetic exploration of subjectivity in the $20^{\text {th }}$ century, Galanaki challenges collective imaginary ideals and proposes accepting history as impassable 
truth, a locus of entanglements, regressions, repetitions, repudiations, forgetting, revisions, defences, and fragments, all of which resist the 'orthos logos' of a definitive interpretation of the past. Such a wandering in the Labyrinth of the city and the past is highly political: the ruins are acknowledged and buried. Their truth is acknowledged but remains impassable. Likewise, the transformation of Europa shutters the myth of the birthplace of European identity: the culture that 'bore' European civilization also bore monsters. This pharmacological understanding of the myth of origin transcends blame and aggression towards the other.

\section{THOUGHTS FOR AN ALTERNATIVE FUTURE}

In this article I have tried to highlight ways of rethinking the predicament of Greek melancholia through Rhea Galanaki's I Akra Tapeinosi. Lines of flight need to be opened when all roads appear to be blocked. The conceptual separation of catastrophe ('national tragedy') from ontological loss helps us on the way. In order to survive catastrophe, Eigen writes, the psyche must translate initial catastrophic globs of experience into psychically soluble events. The challenge is to build an emotional sign language from our sense of catastrophe as a step towards thinking about ourselves (Eigen, 2004: 223). Literature, I would argue, forms an integral part for this effort, performing a double-edge assault on experience and imagination. It provides the poetry capable of reactivating the social body, away from stock metaphors, the synchronic impoverishment of memory and clichés of national tragedy. As a creative linguistic activity the novel constitutes a political activity aiming to replace the foreclosure of thought, even when giving up an object can be seen as betrayal (see Virno, 2004). It puts forward a truth that has a grammar of its own and firmly belongs to a language important for political change.

Care for the other also jostles with myths of greatness. The prospect of change does not require a revolution but a paradigmatic shift (Berardi, 2012: 66). Virno writes: 'those without a home have no option but to behave as thinkers' (2004: 38). Critical thought is not imprisoned in past suppositions or bourgeois homes. Berardi argues that financial insolvency leads to social insolvency (2013: 31) and calls for the right to insolvency (2013: 60, 64). What does this call amount to? Separating ontological lack of being (one's relation to mother and father as well as relation of power) from the spectre of the market as the all-powerful and only Other which defines subjectivity. Subjective freedom arises when the subject puts the Other's (market) role 
into perspective, not when merely succumbing to or denying indebtedness. Opening up the difference and the space that separates ontological from material loss, then, helps dislodges the melancholic attachment to the past. Likewise, care for the other sutures the narcissistic wound of catastrophe by bringing to the fore the other as co-presence, not as an object of investment or commercial value.

Thus, care as relationality and being-with the other is indeed raised into a primary concept. We should draw due attention to this concept. A primary concept refers to a fundamental of being: re-folding experience to the beginning of waiting, reaching the primal scene of an interminable waiting, proceeding to the radical separation of guilt from experience, and of guilt to citizenship, forms a personal-public and ethical posture. Further, care and the reactivation of creativity as responses to psychic dependency - or bondage to use Benjamin's term - alters the despair of 'nothing changes'. In imagining the day after of humiliation and poverty, Galanaki adopts a strategy which is both feminist and radical. First, postural care as ethics proposes we begin to see the dynamics of actuality: inclination as the intertwining of bodies and fates but also as the logic of the non-seer which upends both the tragic model of catastrophe and the imperialism of the mathematical models that drive capitalism. Thus, in true feminist spirit, the logic of care is the counter-discourse to all forms of patriarchal-economic power. Autonomy as the ability to share daily life in solidarity rests on the pleasure of sharing. When this relation is raised into a primary relation it beats the primacy of the capitalist symbolic as the only reality.

A feminist politics of care must emerge 'from the roots'. Roots are not ruins. Roots suggest an affective but not obsessive relationship with the past; witnessing the other and her story while being affected by her, performing a postural ontology qua anti-totalitarian reason; becoming mother and infant but not infantalising or being infantalised. Care is endurance, being fragile and fallible. In thinking a way out of melancholia we might wish to take stock of the efforts to dispel imaginary pasts prior to 2008, before the imaginary watershed of 'catastrophe', to reinvigorate what was already under way at a time that now looks uneventful and dull.

Finally, fear and anxiety are not a solid basis for a community; nor is the feeling of the un-homely (unheimlich) which possesses all those whose home are indebted to the Other. But as more and more citizens are forced to live in the permanent uncanny of a vios xenikos (an 
estranged life in every sense of the word) (Virno, 2004: 38), we are encouraged to return, one more time, to the feminist memory of those imprisoned in someone else's home and power, making that the stringboard of the new political and an act of transgression that can only anticipated the ruins of false imprisonment.

\section{REFERENCES}

Baraitser L (2017) Enduring Time. London: Bloomsbury.

Berardi F (2012) The Uprising: On Poetry and Finance. LA: Semiotext(e).

Butler J (2011) Bodies in alliance and the politics of the street, Lecture given at The European Institute of Progressive Cultural Politics, http://eipcp.net/transversal/1011/butler/en (accessed 10 September 2018)

Cavarero A (2013) Rectitude: Reflections on Postural Ontology. The Journal of Speculative Philosophy 27(3): 220-234.

Cavarero A (2016) Inclinations: A Critique of Rectitude. Stanford: Stanford University Press. Castoriadis C (1997) Word in Fragments, Writings on Politics, Society, Psychoanalysis and the Imagination. Translated by David Ames Curtis. Stanford: Stanford University Press.

Christodoulou N, Rachiotis, G and Anagnostopoulos D (2016) Austerity, economic crisis and their persistent effects on mental health. Psychiatry Today 48(2): 155-160.

Douzinas C (2013) Philosophy and Resistance in the Crisis. London: Polity Press.

Eigen M (2004) The Electrified Tightrope. London: Karnac Books 2004.

Elmarsafy Z (2015) Action, imagination, institution, natality, revolution. Journal for Cultural Research 19(2, 130-138.

Freud, S (1985 [1919]) The Uncanny, in The Standard Edition of the Complete Psychological Works of Sigmund Freud, vol 14, James Strachey (ed) London: Penguin.

Galanaki R (2015) I Akra Tapeinosi. Athina: Ekdoseis Kastanioti.

Galanaki R (2002) O Aionas ton Lavyrinthon. Athina: Edkoseis Kastanioti. 
Glynos J and Voutyras S (2016) Ideology as blocked mourning: Greek national identity at a time of economic crisis, Journal of Political Ideologies 21(3): 201-224.

Halikopoulou D and Vlandas T (2015) The rise of the far right in debtor and creditor European counties: the case of European Parliament elections. Political Quarterly 86(2): 279-288.

Hutnyk J (2012) Proletarianisation. New Formations, 77 (127- 149).

Knight D M (2012) Cultural Proximity: crisis, time and social memory in Central Greece. History and Anthropology 23(3): 349-374.

Kokoli Al (2016) The Feminist Uncanny in Theory and Art Practice. London: Bloomsbury. Lacan, J (1992) The Ethics of Psychoanalysis: The Seminar of Jacques Lacan Book VII. Translated by D Potter. London: Routledge.

Lazzararto M (2012) The Making of the Indebted Man. LA: Semiotext(e).

Lombardo E (2017) The Spanish gender regime in the EU context: changes and struggles in times of austerity, Gender. Work and Organisation 24(1): 20-33.

Malakos T (2018) Blaming the other: an enquiry into the cultural and political preconditions of the Greek crisis. In Fouskas, V K and Dimoulas C (eds) Greece in the $21^{\text {st }}$ Century: The Politics and Economics of a Crisis. London: Routlegde, pp. 187-202.

Rajchman J (1991) Truth and Eros, Foucault, Lacan and the Question of Ethics. New York:

Routledge.

Ross D (2011). Translator's Introduction to Bernard Stiegler's 'Pharmacology of Desire: DriveBased Capitalism and Libidinal Dis- Economy. New Formations, 77, 146- 149.

Sassen S (2013) IPPR, 20(2) 125-128.

Stiegler B (2013) What Makes Life Worth Living: On Pharmacology. Translated by D. Ross. London: Polity Press.

Streeck W (2016) How Will Capitalism End? Essays on a Failing System. London: Verso.

Theodossopoulos D (2014) The ambivalence of anti-austerity imagination in Greece: resistance, hegemony and complicity. History and Anthropology 25(4): 488-506. 
Varoufakis Y (2011) The Global Minotaur: America, the Origins of the Global Crisis and the Future of the World Economy. London: Zed Books.

Virno P (2004) A Grammar of the Multitude: For an Analysis of Contemporary Forms of Life.

LA: Semiotext(e).

Voela A (forthcoming) History, fidelity and time in Rhea Galanaki’s novels, Journal of Modern Hellenism.

Voela A (2011), Heterotopia Revisited: Foucault and Lacan on Feminine Subjectivity. Subjectivity 4(2): $168-182$.

Voela A (2010) Patterns and Scripts: The Revision of Feminine Heterosexuality in Feminist Theory and Literature. European Journal of Women's Studies 18(1): 1-12. 